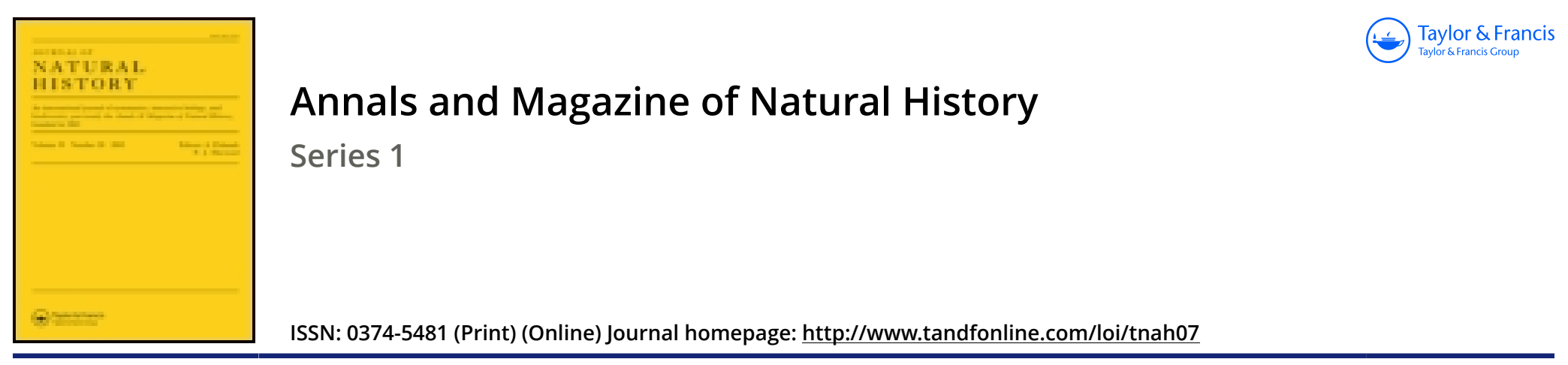

\title{
XXXVII.-On the Structure and Homology of the Cephalic Tentacles in the Pearly Nautilus
}

\section{Prof. Richard Owen F.R.S.}

To cite this article: Prof. Richard Owen F.R.S. (1843) XXXVII.—On the Structure and Homology of the Cephalic Tentacles in the Pearly Nautilus, Annals and Magazine of Natural History, 12:78, 305-311, DOI: 10.1080/03745484309442529

To link to this article: http://dx.doi.org/10.1080/03745484309442529

册 Published online: 04 Dec 2009.

Submit your article to this journal $₫$

Q View related articles $₫$

Citing articles: 1 View citing articles 줄 


\title{
THE A N A L S
}

AND

\section{MAGAZINE OF NATURAL HISTORY.}

\author{
No.78. NOVEMBER 1843.
}

XXXVII.-On the Structure and Homology of the Cephalic T'entacles in the Pearly Nautilus. By Prof. Owns, F.R.S.

To the Editors of the Annals of Natural History.

Gentlemex,

I nave: been faroured with a letter from Prof. Vrolik, in which he writes: "We found the situation of the soft parts of the Pearly Nantilus in the shell, quite as you supposed and exposed in your first plate. It is, indeed, as if that plate was made from our original. The relative position of the different parts is consequently the same as you fancied that it ought to be, and $I$ am, indeed, happy that I have the opportunity of giring such a confirmatory statement. The only difference should be, that what you call the 'dorsal fold' applied to the involute convexity of the shell has not exactly the form and the position you ascribed to it. According to our observations, the mantle forms, at the basis of what you said to be the hood or ligamentous dise ( $n$, plate 1.), a double fold, of which the superior part is thin and loose, the inferior firm and connected with the mantle. This part forms a sort of lip, and the whole fold is applied to the involute convexity of the shell. I am afraid that this will not be completely clear, but I hope that by our future plates our meaning shall be better explained. For the moment this must be sufficient. It shall prove to you that the difference between what you said and what we saw is very small. Perhaps a short indication will be quite enough for the Journal."

I am glad to be able to refer my friend to page 12 and plate 3. fig. $1 . i$ of my memoir on the Pearly Nautilus, in which the part of the double fold which he mentions as forming 'a sort of lip,' is described and figured as the 'semilunar ridge from which the mantle is continued to form the concare fold.' Thus the supposcd difference disappears.

There is one important point in the anatomy of the Pearly Nautilus to which the learned anatomists and naturalists of Holland, in their notice of the specimen dissected by them, have not Amm. \&Mag. N. Hist. Vol. xii. 


\section{Prof. Owen on the Structure of the Pearly Nautilus.}

referred, viz. the structure and signification of the sheathed cephalic tentacula.

II. Valenciennes*, confirming without further detail my description of these organs, proposes a different explanation of their analogies : he compares the sheath of the tentacle to the acetabulum or sucker on the arms of the Dibranchiate Cephalopods, and the tentacle itself to the caruncle of the sucker, and he divides these supposed modified and gigantic acetabula into cight grouns, corresponding with the cight arms of the Octopus. I have, in reference to this ingenious view, re-examined more minutely the intimate structure of the tentacula of the Nautilus, and compared it with that of the arms of the higher Cephalopods, and the following account, from the Hunterian Lectures for 1843, of the structure and homology of the tentacula of the Pearly Nautilus may be acceptable to your readers whose attention has been recently called to the anatomy of that rare and interesting mollusk by the letter of Prof. Vrolik.

"The anterior or muscular division of the Nautilus, which may be termet the head, forms a strong and wide sheath, containing the mouth and its more immcdiate appendages; its inner surface is for the most part smooth, the outer one divided and extended into many parts or processes. The chief of these forms a broad triangular muscular plate or hood covering the upper part of the heal, and presenting a middle and two lateral supcrficies; the former being traversed by a median longitudinal furrow, indicating the place of confluence of the two large hollow tentaculiferous processes of which it is composed. Each side of the head supports a group of perforated processes or digitations, the largest of which is next the hood, and the rest decrease in size as they descend in position. Exclusive of the short, subocular, perforated process $\dagger$, the digitations are eighteen in number on each side, disposcd irregularly, but all directed forwards, some not reaching as far as the anterior margin of the head, others projecting a few lines beyond it. They are of a conical, subtrihedral form, and are hollow: the large one next the confluent pair which forms the hood has, like that part, a papillose outer surface. Each process contains a long and fincly annulated tentacle of a subtrihedral form, with the inner surface incised, as it were, by decper and fewer cuts (fig. l. c), so as to present the appearance of a number of closeset transverse plates, slightly indented by a median longitudinal impression (fig. 2. $f$ ). This modification must increase the prehensile and sentient propertics of the inner surface of the tentacle,

- Nouvelles Recherches sur le Nautile Flambé, Archives du Muséum, 4to. 1839.

+ Particularly described and shown not to be tentaculiferous by M. Valenciennes. 
and it is on the corresponding part of the larger and fewer tentacles of the Dibranchiate Cephalopods that the acetabula are developed. The angle between the two outer finely annulated surfaces $(g)$ subsides near the end of the tentacle, which thus becomes flattened.

"To the ninetcen tentacula which are supported by the confluent and free digitations on cach side of the head, two others must be added which project from very short sheaths, one before, the other behind, the eye; the lateral transwerse incisions are deeper in these than in the digital tentacles.

"Both mandibles are horny, with their tips encased by dense calcarcous matter and their base implanted in the thick muscular parietes of the mouth. They are immediately surrounded by a circular fleshy lip with a plicated anterior bordcr, cxtemal to which thcre are four broad flattened processes continued forwards from the inner surface of the oral sheath, two of which are superior, posterior and external, the other two are inferior, anterior, and more immediatcly enbracing the mouth : the latter are connected together along their inferior margins by a midlle lobe, the inner surface of which supports a series of longitudinal lamelle. On the inner surface of the oral sheath beneath these processes there are two clusters of soft conical papillx, and on each sidc of these a group of lamella. Each of the four processes, which I have called 'labial,' is pierced by twelve canals, the orifices of which project in the form of short tubular processes from the anterior margin, and each canal contains a tentacle similar to, but somewhat smaller than, those of the digitations. Thus the number of tentacula with which the Pearly Nautilus is provided amounts to not less than nincty, of which thirty-eight are termed digital, four ophthalmic, and forty-cight labial. In the second specimen of this rare molluscous animal, presented to the Collere of Surgeons by Captain Sir Ldward Belcher, R.N., there was a slight difference in number in the digital tentacula of the two sides, ninetcen being on the right, and screnteen on the left side. The labial processes in the specimen of Nantilus described by M. Valenciennes contained thirtecn tentacles instead of twelse; and some slight variation is not surprising in the number of prehensile organs developed in such unwonted profusion in the Nautilus.

"The retraction of the tentacula is effected by longitudinal muscular fibres, their elongation by transicrse fibres. These are not, howerer, disposed in circular or spiral series, so as to attenuate and lengthen the tentacle by a general compression, but present a more conplex and beautiful disposition, by which they diminish the transverse diameter without compressing the central nerve. The transwerse fibres (fig. 2. a) arise in nunicrous and 
distinct fasciculi from the dense cellular tissuc (fig. 2. $b$ ), surrounding the nerve in the centre of the tentacle (fig. 2. $d$ ), and radiate at equal distances to the circumference; they divide and subdivide as they diverge, and also send off lateral fibres, which form a delicate netroork in the interspaces of the rays, especially at the angles: the meshes include the longitudinal fasciculi, the cut ends of which are shown at $c$, fig. 2 .

"The mechanical arrangenent of the contractile fibres is very similar to that of the complex muscles described by Cuvier in the proboscis of the elephant. The attenuation and elongation of this brobdignagian tentacle must be effected without compressing the central breathing-tubes, and the transwcrse fibres accordingly radiate from the dense ligamentous tissue which surrounds the tubes : the same prospective contrivance is manifested to prevent the compression of the nerves and ressels in the muscular systcm of the ninety proboscides of the Nautilus.

"The papilla upon the exterior surface of the two large confluent digital processes forming the hood, and of the two hollow digitations next in size inmediately beneath them, forn a remarkable character in the Nautilus, on account of their obvious similarity to tactile papilla; but the sense of touch must be specially cxercised by the numerous cephalic

Fig. 2.
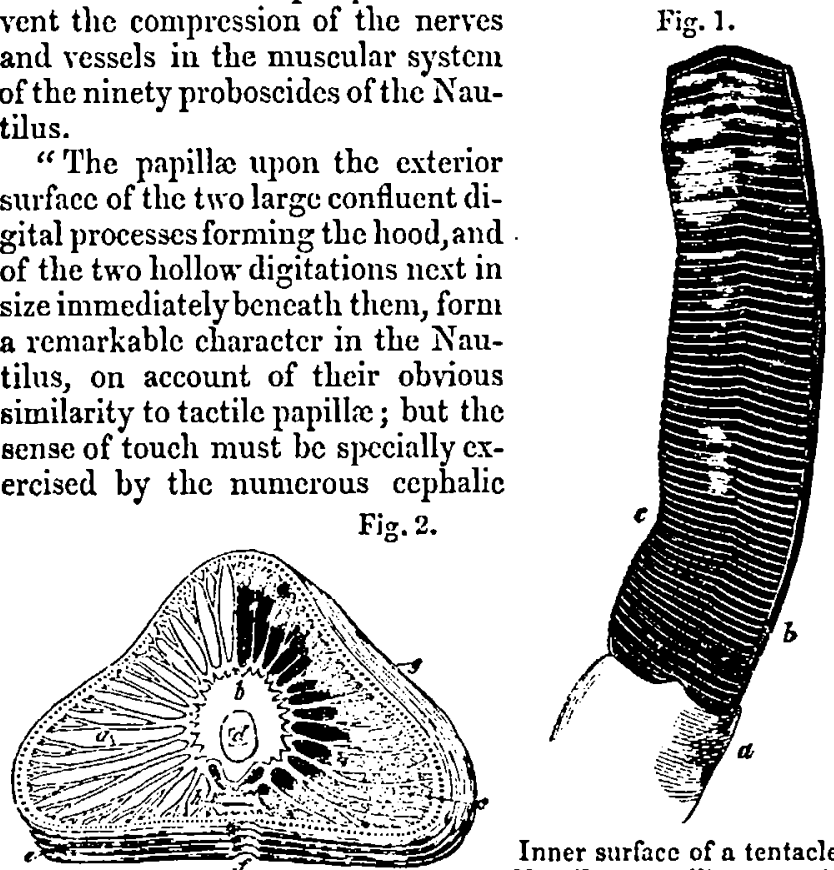

Section of tentacle (Nautilus) magnified. Nautilus pompilius, magnified.

tentacles, which, from their softness of texture, and especially their laminated inner surface (fir. 2. $e, f$ ), are to be regarded as organs of exploration not less than as instruments of prehension.

"I shall now submit my grounds for believing that the corresponding organs in the Dibranchiate Cephalopods are the appendages developed from the head, termed 'arms,' 'feet,' ' tentacles,' 
and 'proboscides.' They have no true homology with the locomotive members of the Vertebrata, but are analogous to them, inasmuch as they relate to the locomotive and prehensile faculties of the animal.

"The eight arms of the Octopus commence by a hollow cone of muscular fibres, attached by a truncated apex to the anterior part of the cephalic cartilage. 'The fibres are for the most part oblique, and interlace with one another in a close and compact manner as the cone advances and expands to form the carity containing the mandibulate mouth, at the anterior extremity of which they are continued forward, and separate into eight distinct portions which form the arms. The derelopment of the eight external arms bears an inverse proportion to that of the boly: they are longest in the short round-bodied Octopi, and shortest in the lengthened Calamaries and Cuttle-fishes, in which the two elongated retractile tentacles are superadded by way of compensation. These Iatter organs are not continued from the muscular cone, which corresponds with the great cephalic sheath supporting the exterior tentacula in the Nautilus, but arise, like the internal labial processes in that Cephalopod, close together from the cephalic cartilage, internal to the origins of the ventral pair of arms. They proceed at first outwards to a large membranous carity situated anterior to the eyes, and emerge between the third and fourth arms on cither side.

"The internal surface of the arms is that which is specially modificd in the Dibranchiate Cephalopods, as in the Nautilus, for the prehensile and tactile faculties; but the structure is much more complicated in the higher order, or Dibranchiata. On this surface each arm supports a single or double scrics or more numerous rows of acetabula or circular sucking-cups : in the clongated pair of superadded tentacles of the Decapods, the suckers are limited to the expanded extremities, where they are gencrally aggregated in more numerous and irregular rows. These tentacles serve to seize a prey which may be beyond the reach of the ordinary arms, and also act as anchors to moor the Cephalopod in some safe harbour during the agitations of a stormy sea.

"Each muscular arm is perforated near the centre of its axis for the lodgement of its nerve and artery, which are surrounded by a layer of cellular tissue; from the dense outer sheath of this cellular canal the transverse fibres of the arm radiate to the periphery, intercepting spaces containing the longitudinal fibres of the arm, the whole being surrounded by two thin and distinct strata of fibres, of which the external is longitudinal, and the internal transverse.

"The mechanical structure of the acctabulum may be favourably studicl in the Octopus, in which those organs are of large size 
and sessile. The circumference of the disc of the sucker is raised by a tumid margin ; a scries of slender folds of membrane, covering corresponding fasciculi of nuscular fibres, converge from the circumference towards the centre of the sucker, where a circular aperture leads to a cavity which widens as it descends, and contains a soft caruncle, rising from the bottom of the cavity like the piston of a syringe. When the sucker is applied to any surface for the purpose of allhesion, the piston, which previously filled the cavity, is retracted and a racuum produced.

"In the Omychoteuthis the caruncle supports a long, curved, sharp-pointed claw. These formidable weapons are sometimes clustered at the cxpanded terminations of the tentacles, and in a few species are arranged in a double alternate scries along the whole internal surface of the cirht ordinary arms, as they were in the extinet Belemnitc.

"In the diminished number, increased size and progressive complication of the cephalic muscular appendages, and in their final modification, in the two long superadded tentacula of the Onychoteuthis, for combining with one another to produce a determinate action, we trace the common order which regulates the development of other parts of the animal organization. In our past revicw of the Invertebrata, we have witnessed this law in the appearance of the more essential organs, as the stomach, the heart, the gills, the geuerative organs; we find it equally regulating the development of the peculiar prehensile instruments of the Cephalopodic class.

"At first very numerous, comparatively small and feeble, essentially alike, the cephalic tentacles of the Nautilus strikingly illustrate the principle of vegetative or irrelative repetition. Their primary import is however plainly indicated by the direct derivation of their central nerve from the cephalic ganglion; and they present the same complex plan of arrangement of their muscular fibres which characterizes the arms and tentacles of the Dibranchiate Cephalopods. The prehensile surface of the tentacula of the Nautilus is made adhesive after the type of the sinple lamiuatcd sucker of the Remora; the median longitudinal impression which partially divides the lamella may represent the complete interspace which separates into two series, in the arms of most of the Dibranchiates, the more complex suctorial appendages which are devcloped on their internal surface : but at all events, the reduction of these arms in number, their augmentation in size, and perfection as prehensile instruments by the superadded complications, are phrenomena which ordinarily attend the march of development. The order of this progress would be anomalously reversed if the tentacles of the Nautilus represented, as MI. Valenciennes supposes, the caruncles of the acctabula, and the hollow 
processes of the oral sheath the caritics of those appendages of the arms of the Dibranchiata. According to the lirench malacologist, the anterior circumference of the head or oral sheath in the Nautilus represents four of the eight arms descloped therefrom in the Dibranchiata ; and the two dorsal arms consist each of two enormous acetabula, whose cavities are deepened into tubes, and whose caruncles are produced into tentacula as highly organized in regard to their nerves and muscles, as are the acetabuliferous arms themselves in the higher order of Cephalopods. The four other arms of the Octopus are represented, according to MI. Valenciennes, by the four groups of tentacula which are included within the oral sheath in the Nautilus. Such is not, howerer, the place of origin of any of the cight arms in the Dibranchiata; nor is it conformable with the gencral liw of development, that a prehensile organ, consisting of tro larere and highly complicated acetabula in a low organized Cephalopod, should support two hundred smaller and more simple suckers in the higher organized species."

Such are the additional facts and arguments which lead me to reject the new views propounded by MI. Valenciennes respecting the sheathed tentacula of the Nautilus, and to uphold the interpretation which I originally gave of their essential nature and analogies. In dissenting from my estcemed friend, I must acknowledge that his peculiar views chicfly stimulated $\mathrm{mc}$ to that closer investigation of the structure of the tentacula which has led to my observation of the special modification of their internal surface and of the arrangement of their muscular structure, which had becn overlooked both by myself in the first description of the Nautilus, and by M.Valenciennes. I shall, in the second edition of my memoir on its organization, add some other particulars of the minute anatomy of the Nautilus, and meanwhile look forward with great interest to the extended memoir of Professors Vrolik and Van Breda, especially in reference to the homologies of the sheathed tentacula. I should wish, in conclusion, to call their attention to the 'elongated pyriform. sac' described by me at p. 35. pl. 5. fig. 18. connected with the ventricle, and which does not appear to have attracted the attention of M. Valenciennes.

I have the honour to be, Gentlemen, Your very obcdient servant, Richard Owen.

London, Sept. 13, 1813. 